\title{
Disruption of Neurotransmission, Membrane Potential, and Mitochondrial Calcium in the Brain and Spinal Cord of Nile Tilapia Elicited by Microcystis Aeruginosa Extract: An Uncommon Consequence of the Eutrophication Process
}

\author{
Minerva Nájera-Martínez \\ Instituto Politecnico Nacional \\ Goretti Guadalupe Landon-Hernández \\ Instituto Politecnico Nacional \\ José Pablo Romero-López \\ Instituto Politecnico de Leiria \\ María Lilia Domínguez-López \\ Instituto Politecnico de Lisboa Instituto Superior de Engenharia de Lisboa \\ Ethel Awilda García-Latorre \\ Instituto Politecnico Nacional \\ Armando Vega-Lopez ( $\sim$ avegadv@yahoo.com.mx ) \\ Instituto Politécnico Nacional, Escuela Nacional de Ciencias Biologicas https://orcid.org/0000-0001-8827-4353
}

\section{Research Article}

Keywords: Mitochondrial dysfunction, Neurotoxicity, Norcantharidin, Pollutants

Posted Date: February 10th, 2021

DOI: https://doi.org/10.21203/rs.3.rs-177703/v1

License: (c) (i) This work is licensed under a Creative Commons Attribution 4.0 International License. Read Full License

Version of Record: A version of this preprint was published at Water, Air, \& Soil Pollution on December 23rd, 2021. See the published version at https://doi.org/10.1007/s11270-021-05480-x. 


\section{Abstract}

Microcystins (MCs) are produced during the growth and proliferation of some species of cyanobacteria, mainly Microcystis aeruginosa, which has massive growth in eutrophic water bodies. Microcystins are highly toxic Microcystisderived metabolites that exert its main effect in the liver through the inhibition of protein phosphatase (PP1 and PP2A). However, other damages in fish species are less documented and could be unexpected. The aim of the current study was to evaluate the effects of Microcystis aeruginosa extract (MaE) into the central nervous system (CNS) of the Nile tilapia. The MaE was normalized by MCs content (MC-LR). We include a positive control for protein phosphatase inhibition, norcantharidin intraperitoneally dosed at sublethal levels. On the eighth day, measurement of neurotransmission biomarkers ( $\mathrm{AChE}, \mathrm{BChE}, \mathrm{CbE}$ and $\mathrm{GABA}$ ) were measured, as well as levels of mitochondrial calcium, and the mitochondrial membrane potential by flow cytometry in the brain and spinal cord were assessed, in addition to the PP1/PP2A activity in the liver. The MCs elicited mortality at $5 \mu \mathrm{g} / \mathrm{L}$. The positive control and MCs at sublethal levels inhibited the PP1/PP2A activity in the liver and induced alterations in the neurotoxicity biomarkers evaluated in the CNS. This response is probably due to the disruption of transport ions, dependent and independent of ATP because of alterations in the mitochondrial membrane potential and mitochondrial calcium. The findings of this study suggest that pollutants capable of inducing cyanobacterial blooms are able, in an indirect way, to exert neurotoxic effects in fish species through MC levels.

\section{Introduction}

Microcystins (MCs) are toxins (secondary metabolites) produced by cyanobacteria (blue-green algae), primarily Microcystis aeruginosa, forming blooms worldwide, particularly in tropical and temperate environments. MCs are hepatotoxic cyclic heptapeptides released into the water during or on senescence of cyanobacterial blooms (Harada and Tsuji 1998; Malbrouck and Kestemont 2006). MCs are the most common of the cyanobacterial toxins found in freshwater, and are being often responsible for poisoning terrestrial animals, including livestock, wildlife, and humans who are exposed to MC-polluted water (Carmichael et al. 2001). By these reasons, there is an increasing concern all over the world due to the acute and chronic effects on humans and wildlife from the MCs linked with water pollution. MCs are potent and highly specific hepatotoxinas due to the inhibition of type-1 (PP1) and type-2A (PP2A) protein phosphatases (Harada and Tsuji 1998; Gupta et al. 2003; Mikhailov et al. 2003). A large number of studies have documented the hazardous potential of MCs in aquatic organisms as well (e.g. Chorus and Bartram 1999; Landsberg 2002; Wiegand and Pflugmacher 2005; Olivares-Rubio et al. 2015).

However, some studies have also indicated behavioural changes and neurotoxic effects induced by MCs on fish species. In embryo and adult zebrafish (Danio rerio) and moderlieschen (Leucaspius delineatus), there is evidence ofalterations in swimming activity and spontaneous locomotor behaviour after MC-LR exposure (Baganz et al. 1994; Baganz et al. 2004; Kist et al. 2012). This was also seen in embryo zebrafish exposed to Planktothrix agardhii containing MC-YR and MC-LR (Jonas et al. 2015) and treated with pure MC-LR (Wu et al. 2016). Other studies on Jenynsia multidentata reported changes in swimming activity by acute MC-LR exposure (100 $\mathrm{\mu g} / \mathrm{L})$, as well as anxiogenic effects with a decrease of almost $63 \%$ in swimming distance and an increase in the immobility time (Cazenave et al. 2008). Interestingly, the parental MC-LR exposure of zebrafish induced larvae hypoactivity related to alterations in neurotransmitter systems and neuronal development by transfer of this toxin to the offspring (Wu et al. 2017). The neurotoxicity biomarkers showed that the $M$. aeruginosa extract containing MC-LR decreased the AChE activity in the rainbow trout (Gélinas et al. 2012) as in newly hatched zebrafish (Qian et al. 2018) or embryo zebrafish treated with MC-LR alone (Wu et al. 2016). In contrast, a significant increase in the metabolism of this enzyme in zebrafish by MC-LR-waterborne exposure was reported (Kist et al. 2012). In spite of preceding reports, there are no available studies in the Nile tilapia, as in many other fish species. Therefore, the study aim was to evaluate the 
neurotoxic effects of a wild strain of Microcystis aeruginosa extract at sublethal concentrations in the brain and spinal cord of juvenile Oreochromis niloticus through measurement of neurotransmission biomarkers (AChE, BChE, CbE, and GABA), levels of mitochondrial calcium, and mitochondrial membrane potential. We will also compare these damages tothose induced by a specific inhibitor of the PP1/PP2A activity, norcantharidin.

\section{Materials And Methods}

\section{ObtainingMicrocystis aeruginosa strain and its crude extract}

The algae were attained fromthe upper layer of a freshwater body with a visible degree of eutrophication, being careful to take part of the top creams of green tones. The obtained sample was taken from Tezozomoc Park in Mexico City, bordering to the north with the municipality of Tlalnepantla and to the northwest with the municipality of Naucalpan into the State of Mexico, between the coordinates $19^{\circ} 29^{\prime} 05^{\prime \prime} \mathrm{N}$ and $99^{\circ} 12^{\prime} 36^{\prime \prime} \mathrm{W}$. The biomass was cultured by cross streak in petri dish containing agar dissolved with sterile f/2 medium (Guillard, 1975). Permanent slides were prepared of isolated specimens using standard techniques for microalgae. Observations were made with a Zeiss optical microscope equipped with a Canon PowerShot G6 digital camera and identified by Komárek and Anagnostidis (2005) and Guiry in Guiry and Guiry (2020) criteria. Once the cyanobacterium was identified as Microcystis aeruginosa, stock cultures were grown in sterile $\mathrm{f} / 2$ medium in $4 \mathrm{~L}$ glass bottles at $22 \pm 2^{\circ} \mathrm{C}$ supplied with continuously bubbling air and irradiated with white fluorescent tubes ( $516 \pm 50$ lux) with nonstop light for at least three weeks to reach its exponential growth and its begin in the decay phase. The biomass was centrifuged at 2,500 rpm, and the extract was obtained with methanol at $65^{\circ} \mathrm{C}$ using a Soxhlet extractor for $8 \mathrm{~h}$. The methanolic extract was concentrated with a rotary evaporator. The quantification of MCs in the methanolic extract was performed using Shimadzu high-performance liquid chromatography (HPLC) with an Agilent Technologies column (4.6 x $250 \mathrm{~mm})$. The reference standard was purchased from Sigma-Aldrich (Sulpeco ${ }^{8}$, cat. 33578,) certified as microcystin RR-YR-LR solution ( $5 \mu \mathrm{g} / \mathrm{mL}$ in methanol,each) following analytic procedures previously documented (Olivares-Rubio et al. 2015). The Microcystis aeruginosa methanolic extract rendered a value of $1.65 \pm 0.07 \mu \mathrm{g} / \mathrm{mL}$ of MC-LR plus MC-RR and $0.09 \pm 0.001 \mu \mathrm{g} / \mathrm{mL}$ of MC-YR.

\section{Short-term Exposure}

Juvenile specimens of Nile tilapia (Oreochromis niloticus) were obtained from a fish farm and were maintained under laboratory conditions in agreement with Article 38 and Chapter V of the Directive 2010/63/EU of the European Parliament and of the Council of 22 September 2010 for the protection of animals used for scientific purposes (https://eur-lex.europa.eu/legal-content/EN/TXT/?uri=celex\%3A32010L0063). The Nile tilapia ( $\mathrm{n}=8 /$ treatment) of $10.54 \pm 0.17 \mathrm{~cm}$ (mean \pm SEM) were subjected to a short-term exposure of $8 \mathrm{~d}$. The test MC concentration was established considering the value proposed by the World Health Organization (WHO) of $1 \mu \mathrm{g} / \mathrm{L}$ as the maximum permissible limit in water for human consumption. Higher values ( 5 and $10 \mu \mathrm{g} / \mathrm{L}$ of MCs) were also included. The control group for MC water exposure was methanol with a concentration of $0.001 \%(\mathrm{v} / \mathrm{v})$ and semi-hard synthetic water as the absolute control. The levels of positive control for PP1/PP2A inhibition (norcantharidin, Sigma-Aldrich ${ }^{\circledR}$, cat.

N8784) were established based on acute tests (25 to $2.5 \mathrm{mg} / \mathrm{kg})$. The $\mathrm{DL}_{10}(1.0 \mathrm{mg} / \mathrm{kg})$ was selected as the higher dose for short-term exposure, additionally, in a logarithmic way, two doses below $(0.1 \mathrm{mg} / \mathrm{kg}$ and $0.01 \mathrm{mg} / \mathrm{kg})$ were intraperitoneally administrated using a saline solution as a vehicle. During the time exposure, fish were fed every three days with pellets $(2 \% \mathrm{w} / \mathrm{bw})$. Due to the nature of the biomarkers under study, it was not possible to use a fish anaesthetic, for this aim, the specimens of 0 . niloticus were anaesthetized on ice and euthanized by fast freeze to obtain the brain, spinal cord, and liver after the exposure. These tissues samples were weighed and stored in buffer solution according to the needs of each biomarker, and homogenized in a Glas-Col ${ }^{\mathrm{TM}}$ homogenizer under an ice bath. For enzymatic evaluations (PP1/PP2A, AChE, BChE, CbE, and GABA levels), PBS1X was used, and the homogenate was 
centrifuged at $9,000 \mathrm{rpm} / 4^{\circ} \mathrm{C} / 15 \mathrm{~min}$ to obtain the $\mathrm{S} 9$ fraction. The fractions were stored at $-80^{\circ} \mathrm{C}$. The total content of proteins was determined using a 2-D Quant Kit GE Healthcare ${ }^{\mathrm{T}}$, using a BSA standard curve from 10 to $50 \mu \mathrm{g}$.

\section{Biomarkers evaluation: PP1/PP2A activity}

A volume of $200 \mu \mathrm{L}$ of $\mathrm{S} 9$ fraction was added to $800 \mu \mathrm{L}$ of buffer $\mathrm{pH} 7.2$ (50 mM imidazole pH 7.2, 2 mM dithiothreitol, $0.5 \mathrm{mg} / \mathrm{ml}$ bovine serum albumin, $5 \mathrm{mmol}$ theophylline, $0.2 \mathrm{mmol} \mathrm{MnC} 12$ ) plus $10 \mu \mathrm{L}$ of $20 \mathrm{mM}$-nitrophenyl phosphate. The mixture was incubated at $30^{\circ} \mathrm{C}$ for 20 minutes in the dark. The reaction was stopped with $200 \mu \mathrm{L}$ of 0.5 $\mathrm{M} \mathrm{Na}_{2} \mathrm{CO}_{3}$, and the absorbance at $410 \mathrm{~nm}$ against reagent blank was determined. Enzymatic activity of PP1/PP2A [EC3.1.3.16] was calculated by the molar extinction coefficient of $p$-nitrophenol of $18,300 \mathrm{mM}^{-1} \mathrm{~cm}^{-1}$ (Silberman et al. 1984). Results are shown as $\mathrm{mMOL} / \mathrm{min} / \mathrm{mg}$ protein.

\section{Acetylcholinesterase activity (AChE)}

The enzymatic determination of AChE [EC3.1.1.7] was performed by the Hestrin method (1949) using a standard curve of acetylcholine chloride (Sigma ${ }^{\circledR}$, cat. A6625) to determine the per cent of inhibition by the presence of hydrolyzed acetylcholine. Fifty $\mu \mathrm{L}$ of the S9 fraction was taken; $125 \mu \mathrm{L}$ of Tris buffer $\mathrm{pH} 7$ and $125 \mu \mathrm{L}$ of standard acetylcholine (10 $\mu \mathrm{moles} / \mathrm{mL}$ ) were added, and it was stirred and incubated at room temperature for 30 minutes. After that time, $250 \mu \mathrm{L}$

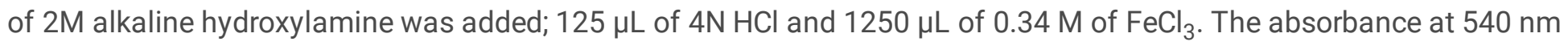
was determined in a microplate Synergy MX spectrophotometer, and was divided by the incubation time to obtain the absorbance per minute, obtaining in this way, the AChE activity ( $\mu \mathrm{M} / \mathrm{min} / \mathrm{mg}$ protein).

\section{Activity of carboxylesterases (CbE)}

The determination of the activity of carboxyl esterases (CbE) [EC3.1.1.1] was carried out in the S9 fraction through the hydrolysis of $p$-nitrophenol acetate to form $p$-nitrophenol $\left(\mathrm{C}_{6} \mathrm{H}_{5} \mathrm{NO}_{3}\right)$ according to Hotta et al. method (2002) with modifications. $50 \mu \mathrm{L}$ of $\mathrm{S} 9$ fraction of and $25 \mu \mathrm{L}$ of Tris- $\mathrm{HCl}(100 \mathrm{mM}$ and pH 8) were placed in 96-well microplates, the mixture was incubated at $37^{\circ} \mathrm{C}$ by 5 minutes, and immediately $150 \mu \mathrm{L}$ of reaction buffer was added. The absorbance was monitored at $405 \mathrm{~nm}$ each minute by five minutes in a microplate Synergy MX spectrofluorometer. The production

of $\mathrm{C}_{6} \mathrm{H}_{5} \mathrm{NO}_{3}$ was calculated using the coefficient of molar extinction of $18,700 \mathrm{M}^{-1} \mathrm{~cm}^{-1}$, proposed by Kumar et al. (2010) for $\mathrm{C}_{6} \mathrm{H}_{5} \mathrm{NO}_{3}$ dissolved in Tris- $\mathrm{HCl}$ at $100 \mathrm{mM}$ and $\mathrm{pH}$ 8.0. Data are display as $\mathrm{mM} \mathrm{C}_{6} \mathrm{H}_{5} \mathrm{NO}_{3} / \mathrm{min} / \mathrm{mg}$ protein.

\section{Activity of butyrylcholinesterase (BChE)}

For quantification of enzymatic activity of BChE [EC3.1.1.8], a volume of $10 \mu \mathrm{L}$ of S9 fraction was placed in a $96-$ well microplate, and $10 \mu \mathrm{L} 6 \mathrm{mM}$ of S-butyrylthiocholine iodide and $180 \mu \mathrm{L}$ of the reaction solution $(50 \mathrm{mM}$ at $\mathrm{pH} 7.7$ of phosphate buffer and a solution of dithiobis nitrobenzoate at $0.25 \mathrm{mM}$ ) were added. The absorbance was evaluated at $405 \mathrm{~nm}$ in periods of 30 seconds $\left(0,30,60\right.$, and 90 seconds) at $37^{\circ} \mathrm{C}$ on a Synergy MY microplate spectrophotometer. The molar extinction coefficient of $23,460 \mathrm{mM}^{-1} \mathrm{~cm}^{-1}$ was used (Knedel and Böttger 1967). Graphs symbolize the activity of $B C h E$ as $\mathrm{mM} / \mathrm{min} / \mathrm{mg}$ protein.

\section{Evaluation of $y$-aminobutyric acid (GABA) levels}

A volume of $400 \mu \mathrm{L}$ of $S 9$ fraction and $400 \mu \mathrm{L}$ methanol HPLC grade was placed in Eppendorf tubes, mixed, and then were centrifuged at $12,000 \mathrm{rpm}$ for 10 minutes at $4{ }^{\circ} \mathrm{C}$ in a refrigerated centrifuge. $350 \mu \mathrm{L}$ of the supernatant, $300 \mu \mathrm{L}$ of borax solution ( $\mathrm{g} / \mathrm{dL}$ in deionized water) $\mathrm{pH} 8$ (Sigma-Aldrich ${ }^{\circledR}$, Cat. HT1002), and $500 \mu \mathrm{L}$ of derivatizing agent (4hydroxy-1-naphthaldehyde $0.3 \mathrm{w} / \mathrm{v}$ in methanol, Aldrich ${ }^{\circledR}$, cat. 131067) were mixed, incubated at $80^{\circ} \mathrm{C}$ for $10 \mathrm{~min}$, and cooled. This mix was placed in a volumetric flask, and the final volume was adjusted to $5 \mathrm{ml}$ with methanol. Ffinally the 
sample was filtered through $0.45 \mu \mathrm{m}$ syringe filters. The absorbance was evaluated at $330 \mathrm{~nm}$ in a microplate spectrophotometer, with $250 \mu \mathrm{L}$ of the processed sample in each well. The GABA content was estimated with a calibration curve of $4.68-75 \mu \mathrm{g} / \mathrm{ml}$ of $\gamma$-aminobutyric acid certified reference standard TraceCERT ${ }^{\circledR}$ (Sulpecoß, cat. 43811) following the Khuhawar and Rajper (2003) method modified by Vega-Lopez et al. (2019). Results are represented as $\mu \mathrm{M} \mathrm{GABA} / \mathrm{mg}$ protein.

Mitochondrial isolation and analysis of membrane potential $\left(\Delta \psi_{m}\right)$ and mitochondrial calcium ( $\left.m C a^{+2}\right)$ levels

The functional mitochondria wereisolated from the brain and spinal cord with $100 \mu \mathrm{L}$ of buffer $\mathrm{IB}_{\mathrm{c}}$, according with directions proposed by Frezza et al. (2007) for cells and liver mouse cells. The mitochondrial membrane potential $(\Delta \Psi \mathrm{m})$ was evaluated with 3,3'-dihexyloxacarbocyanine iodide $\left(\mathrm{DiOC}_{6}(3)\right.$ at a final concentration of $50 \mathrm{nM}$ using $100 \mu \mathrm{L}$ of isolated mitochondria according to Chang et al. (2013). Although this method was designed for cells, $\mathrm{DiOC}_{6}(3)$ is also useful for the measurement of $\Delta \Psi \mathrm{m}$ in isolated mitochondria (Kataoka et al. 2005). Mitochondrial calcium ( $\mathrm{mCa}^{+2}$ ) was assessed using a Fluo-4 NW Calcium Assay Kit (Thermo Fisher Scientific ${ }^{\mathrm{TM}}$ ) using 125,000 mitochondria/50 $\mu \mathrm{L}$ following the manufacturer protocol. For both stain techniques, stained mitochondria were centrifuged at 10,670xg/10 min, and the supernatant was discarded, $p$-formaldehyde at $0.1 \%$ was added and vortexed for 30 seconds at 1,000 rpm, and the mixture was incubated at room temperature for 30 minutes for preservation. Lastly, the mitochondria were centrifuged, the $p$-formaldehyde was discarded. The pellet was resuspendedin $500 \mu \mathrm{L}$ of DPBS (Chang et al. 2013) and stored at room temperature in darkness until the fluorescence was measured in a Sony SH800 ${ }^{\mathrm{TM}}$ flow cytometer $\left(\right.$ Sony $\left.{ }^{\mathrm{TM}}\right)$. The mean fluorescence intensity was inversely proportional to the $\Delta \Psi \mathrm{m}$, and the Fluo- 4 NW was chemically bound by electronic affinity to the intra-mitochondrial calcium. Data from $\Delta \Psi \mathrm{m}$ and $\mathrm{mCa}^{+2}$ are shown as the mean fluorescence intensity (MFI).

\section{Statistical analysis}

The Shapiro-Wilk test was applied to know the distribution of data and most passed the normality test. Hence, the biomarkers results were analysed by one-way analysis of variance (ANOVA) followed by Dunnet's comparison Test. The Kruskal-Wallis and Mann-Whitney $U$ tests were used for the statistical analysis of mean fluorescence intensity of $\Delta \Psi \mathrm{m}$ and $\mathrm{mCa}^{+2}$, using the software for descriptive statistics, "GraphPad Prism 6" (GraphPad Software, San Diego, California, USA, www.graphpad.com). We considered statistical significance at a value of $p \leq 0.05$ for all tests. With the aim to compare the effects elicited by $M$. aeruginosa extract with those damages induced by the positive control of PP1/PP2A inhibition (norcantharidine) on the CNS organs, we employed the "Integrated Biological Response version 2" (IBRv2) analysis developed by Sanchez et al. (2013), which is a helpful tool in the interpretation of these variables under both field and controlled conditions (Olivares-Rubio et al. 2013; Dzul-Caamal et al. 2016). Also, we applied a parametric correlation analysis (Pearson) to know the possible relationships among neurotoxicity biomarkers.

\section{Results}

\section{PP1/PP2A activity}

The inhibition of the enzymatic activity of PP1/PP2A in the liver of the Nile tilapia elicited by the M. aeruginosa extract (MaE) was significantly decreased, even at doses of MC-LR considered safe (Fig. 1A). Similarly, the NCTD induced an abolishment of this catalysis in a dose-dependent manner (Fig. 1B).

\section{Activity of enzymes involved in neurotransmission (AChE, CbE, and BChE)}


The catalysis of AChE was irregular and did not respond consistently among the studied organs of the Nile tilapia exposed to M. aeruginosa extract (MaE) and dosed with NCTD. In the brain (Fig. 2A) and spinal cord (Fig. 2B) of specimens treated with $\mathrm{MaE}$, an uneven response was found, which was only significant in the spinal cord at $5.0 \mu \mathrm{g} / \mathrm{L}$. A similar patter occurred in the brain of fish dosed with NCTD (Fig. 2C); however, the low and medium doses of this substance increased the AChE activity in the spinal cord (Fig. 2D).

Interestingly, CbE activity in the brain of fish treated with MaE (Fig. 2E) or with NCTD (Fig. 2G) decreased in both cases, but it was significant only for NCTD. In contrast, in the spinal cord of $O$. niloticus exposed to 1.0 and $10.0 \mu \mathrm{g} / \mathrm{L}$ of MaE (Fig. 2F), as well as for three doses of NCTD (Fig. 2H), significant decreases were found.

As was the case for the others esterases, the BChE in the brain seems to be statistically unaltered by toxicants able to inhibit PP1/PP2A, such as was the case for MaE (Fig. 2I) with the exception of the high dose of NCTD (Fig. 2K), which increased the activity of this enzyme. However, the median concentration of MaE elicited a significant increase of BChE in the spinal cord (Fig. 2J). This was not seen with NCTD, despite a similar response (Fig. 2L).

\section{Levels of GABA}

Despite previous findings, the levels of GABA were not consistently affectedin the organs studied. The GABA levels in the brain decreased at $5 \mu \mathrm{g} / \mathrm{L}(\mathrm{p} \leq 0.05)$, and also at the high concentration of MaE (Fig. 3A); notwithstanding, in the spinal cord, (Fig. 3B) levels of this neurotransmitter decreased at $1.0 \mu \mathrm{g} / \mathrm{L}$ and increased at $5.0 \mu \mathrm{g} / \mathrm{L}(\mathrm{p} \leq 0.05)$. In a general way, the effects of NCTD showed a depletion of GABA in the brain (Fig. 3C), which was significant at $0.01 \mu \mathrm{g} / \mathrm{kg}$ $(p \leq 0.5)$, as was also detected for the spinal cord (Fig. 3D).

\section{Mitochondrial membrane potential $(\Delta \Psi \mathrm{m})$ and mitochondrial $\mathrm{Ca}^{+2}$ levels $\left(\mathrm{mCa}^{+2}\right)$}

In the brain, the MaE does not cause any significant change in $\Delta \Psi \mathrm{m}$; however, a decrease was noted with high concentration of this extract (Fig. 4A). Nevertheless, in the spinal cord, a significant increase in the $\Delta \Psi_{\mathrm{m}}$ (decrease of MFI of $\mathrm{DiOC}_{6}$ ) was found at 5.0 and $10.0 \mu \mathrm{g} / \mathrm{L}$ of MC-LR (Fig. 4C). Fish dosed with NCTD showed a decrease in $\Delta \Psi \mathrm{m}$ in the brain, particulary when treated with a high dose (Fig. 4B). This also occurred in the spinal cord of the Nile tilapia dosed with $0.01 \mu \mathrm{g} \mathrm{NCTD/kg} \mathrm{(Fig.} \mathrm{4D).}$

In contrast, the level of $\mathrm{mCa}^{+2}$ was statistically abolished in the brain of Nile tilapia treated with MaE (Fig. 4E), as was also noted in the spinal cord of fish treated with the medium and high concentrations of MC-LR (Fig. 4G). However, in fish dosed with NCTD, the levels of $\mathrm{mCa}^{+2}$ increased $(\mathrm{p} \leq 0.001)$ in the brain of 0 . niloticus exposed to $0.01 \mu \mathrm{g}$ NCTD/kg (Fig. 4D), as well as in the spinal cord ( $\mathrm{s} \leq 0.001$ ) in the treatments of 0.01 and $0.1 \mu \mathrm{g} \mathrm{NCTD/kg} \mathrm{(Fig.} \mathrm{4F).}$

\section{Star plot areas obtained from Integrated Biological Response version 2 (IBRv2)}

The integration of the biological response exhibited a clear neurotoxic effect exerted by both MaE and NCTD regarding their own controls, particularly in fish exposed to medium and high concentrations or doses. At the lower MaE concentration, the star plot area showed that the spinal cord was more affected than the brain. In fish exposed to 5.0 $\mu \mathrm{g} / \mathrm{L}$ and $10 \mu \mathrm{g} / \mathrm{L}$ of $\mathrm{MaE}$, the damage had a similar response between both organs. Likewise, GABA levels, $\Delta \Psi \mathrm{m}$, and $\mathrm{mCa}^{+2}$, and to some extent $\mathrm{CbE}$ activity, suffered the most with regard to basal values (Fig. 5 left panels). In contrast, the neurotoxicity elicited by NCTD was more consistent between organs and doses, and the response of the neurotoxicity biomarkers was similar than those elicited by MaE including to PP1/PPA2 in the liver (Fig. 5 right panels). 


\section{Correlation between biomarkers}

In agreement with the findings of the star plot area obtained from IBRv2, the Pearson moment correlation analysis proved that MaE (Table 1) and NCTD (Table 2) caused neurotoxicity. This hypothesis is feasible to occur by increases in the number of correlations (negative and positive) between biomarkers compared with those observed in the control groups. Basal values of GABA in the brain were inversely related to AChE in the spinal cord and with $\mathrm{CbE}$ in the brain in both control groups. In MaE treatment control group, the results displayed a negative correlation among brain $\mathrm{CbE}$ with $\mathrm{AChE}$ in the spinal cord, but positive in the brain. In the same controls, brain AChE exhibited a positive correlation with the PP1/PP2A in the liver, and the activity of BChE was positively correlated in both nervous system organs (Table 1). Interestingly, in the NCTD group, a posivite correlation between $\triangle \Psi \mathrm{m}$ and GABA was observed in the spinal cord, $\mathrm{mCa}{ }^{+2}$ with $\mathrm{AChE}$, and $\mathrm{BChE}$ with $\mathrm{CbE}$ in the brain of the Nile tilapia. 
Table 1

Correlations between biomarkers in the Nile tilapia (Oreochromis niloticus) treated with Microcystis aeruginosa extract standardized as MC-LR levels (Only significant results are show).

\begin{tabular}{|c|c|c|c|c|c|c|c|c|c|c|c|c|}
\hline & $\begin{array}{l}\text { AChE- } \\
\text { B }\end{array}$ & $\begin{array}{l}\text { AChE- } \\
\text { SC }\end{array}$ & $\begin{array}{l}\text { CbE- } \\
\text { B }\end{array}$ & $\begin{array}{l}\text { CbE- } \\
\text { SC }\end{array}$ & $\begin{array}{l}\text { BChE- } \\
\text { B }\end{array}$ & $\begin{array}{l}\text { BChE- } \\
\text { SC }\end{array}$ & $\begin{array}{l}\text { GABA- } \\
\text { B }\end{array}$ & $\begin{array}{l}\text { GABA- } \\
\text { SC }\end{array}$ & $\begin{array}{l}\Delta \Psi \mathrm{m} \\
-\mathrm{B}\end{array}$ & $\begin{array}{l}\Delta \Psi \mathrm{m} \\
-\mathrm{SC}\end{array}$ & $\begin{array}{l}\mathrm{Ca}^{+} \\
{ }^{2}-\mathrm{B}\end{array}$ & $\begin{array}{l}\mathrm{Ca}^{+2} . \\
\mathrm{SC}\end{array}$ \\
\hline \multicolumn{13}{|l|}{ CTRL } \\
\hline PP & $\begin{array}{l}0.84 \\
\mathrm{p}< \\
0.05\end{array}$ & & & & & & & & & & & \\
\hline $\begin{array}{l}\text { AChE- } \\
\text { SC }\end{array}$ & & & $\begin{array}{l}-0.86 \\
\mathrm{p}< \\
0.05\end{array}$ & $\begin{array}{l}0.86 \\
p< \\
0.05\end{array}$ & & & $\begin{array}{l}-0.84, \\
\mathrm{p}< \\
0.05\end{array}$ & & & & & \\
\hline CbE-B & & & & & & & $\begin{array}{l}-0.93 \\
\mathrm{p}< \\
0.01\end{array}$ & & & & & \\
\hline $\begin{array}{l}\text { BCHE- } \\
\text { B }\end{array}$ & & & & & & $\begin{array}{l}0.85 \\
\mathrm{p}< \\
0.05\end{array}$ & & & & & & \\
\hline \multicolumn{13}{|c|}{$1.0 \mu \mathrm{g} M C-L R / L$} \\
\hline $\begin{array}{l}\text { AChE- } \\
\text { B }\end{array}$ & & & $\begin{array}{l}0.82 \\
\mathrm{p}< \\
0.05\end{array}$ & & & $\begin{array}{l}-0.90, \\
p< \\
0.01\end{array}$ & & & & & & \\
\hline CbE-B & & & & $\begin{array}{l}0.85 \\
p< \\
0.05\end{array}$ & & & $\begin{array}{l}0.93 \\
\mathrm{p}< \\
0.01\end{array}$ & & & & & \\
\hline $\begin{array}{l}\text { BChE- } \\
\text { SC }\end{array}$ & & & & & & & & & & & & $\begin{array}{l}-0.82, \\
\mathrm{p}< \\
0.05\end{array}$ \\
\hline $\begin{array}{l}\Delta \Psi \mathrm{m}- \\
\mathrm{SC}\end{array}$ & & & & & & & & & & & $\begin{array}{l}-0.96 \\
p< \\
0.01\end{array}$ & \\
\hline \multicolumn{13}{|c|}{$5.0 \mu \mathrm{g} \mathrm{MC}-\mathrm{LR} / \mathrm{L}$} \\
\hline PP & & & & & & & & $\begin{array}{l}0.99 \\
p< \\
0.001\end{array}$ & & & & \\
\hline $\begin{array}{l}\text { AChE- } \\
\text { B }\end{array}$ & & $\begin{array}{l}-0.95 \\
\mathrm{p}< \\
0.01\end{array}$ & & & & $\begin{array}{l}-0.98, \\
p< \\
0.001\end{array}$ & $\begin{array}{l}0.85 \\
\mathrm{p}< \\
0.05\end{array}$ & & & & & \\
\hline $\begin{array}{l}\text { AChE- } \\
\text { SC }\end{array}$ & & & & & & $\begin{array}{l}0.99, \\
p< \\
0.001\end{array}$ & $\begin{array}{l}-0.95 \\
\mathrm{p}< \\
0.01\end{array}$ & & & & $\begin{array}{l}0.90, \\
p< \\
0.05\end{array}$ & \\
\hline $\begin{array}{l}\text { CbE- } \\
\text { SC }\end{array}$ & & & & & $\begin{array}{l}0.98 \\
p< \\
0.01\end{array}$ & & $\begin{array}{l}0.88 \\
\mathrm{p}< \\
0.05\end{array}$ & & & & & \\
\hline
\end{tabular}

B: Brain. SC: Spinal cord. PP: PP1/PP2A activity. AChE: Acetylcholinesterase activity. CbE: Carboxyl esterases activity. BChE: Butyryl cholinesterase activity. GABA: $\gamma$-aminobutyric acid levels. $\Delta \Psi \mathrm{m}$ : Mitochondrial membrane potential. $\mathrm{Ca}^{+2}$ : Mitochondrial calcium. 


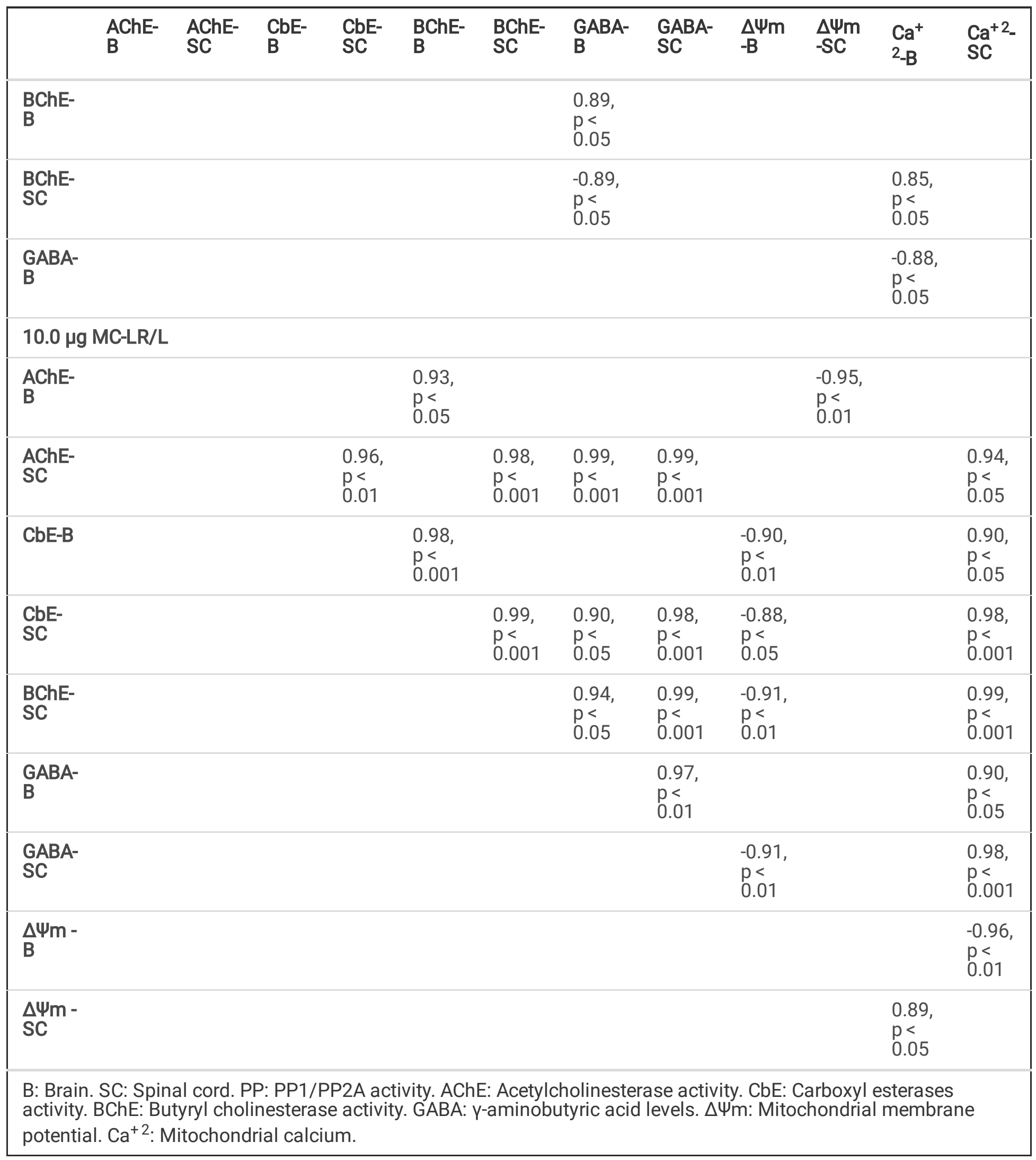


Table 2

Correlations between biomarkers in the Nile tilapia (Oreochromis niloticus) intraperitoneally dosed with norcantharidin (Only significant results are show).

\begin{tabular}{|c|c|c|c|c|c|c|c|c|c|}
\hline & CbE-SC & BChE-B & BChE-SC & GABA-B & $\begin{array}{l}\text { GABA- } \\
\text { SC }\end{array}$ & $\Delta \Psi \mathrm{m}-\mathrm{B}$ & $\begin{array}{l}\Delta \Psi \mathrm{m}- \\
\mathrm{SC}\end{array}$ & $\mathrm{Ca}^{+2}-\mathrm{B}$ & $\mathrm{Ca}^{+2}-\mathrm{SC}$ \\
\hline \multicolumn{10}{|l|}{ CTRL } \\
\hline $\begin{array}{l}\text { AChE- } \\
\text { B }\end{array}$ & & & & & & & & $\begin{array}{l}-0.84, \mathrm{p} \\
<0.05\end{array}$ & \\
\hline $\begin{array}{l}\text { AChE- } \\
\text { SC }\end{array}$ & & & & $\begin{array}{l}-0.91, p \\
<0.05\end{array}$ & & & & & \\
\hline CbE-B & & $\begin{array}{l}0.83, p< \\
0.05\end{array}$ & & $\begin{array}{l}-0.89, \mathrm{p} \\
<0.05\end{array}$ & & & & & \\
\hline $\begin{array}{l}\text { GABA- } \\
\text { SC }\end{array}$ & & & & & & & $\begin{array}{l}0.82, p \\
<0.05\end{array}$ & & \\
\hline \multicolumn{10}{|c|}{$0.01 \mu \mathrm{g} / \mathrm{kg}$} \\
\hline $\begin{array}{l}\text { AChE- } \\
\text { B }\end{array}$ & $\begin{array}{l}-0.88, p \\
<0.05\end{array}$ & & & $\begin{array}{l}0.97, \mathrm{p} \\
<0.01\end{array}$ & & & & & \\
\hline $\begin{array}{l}\text { AChE- } \\
\text { SC }\end{array}$ & & & & & & & & & $\begin{array}{l}0.95, p< \\
0.01\end{array}$ \\
\hline CbE-B & & $\begin{array}{l}0.99, \mathrm{p}< \\
0.001\end{array}$ & & & & & $\begin{array}{l}0.82, \mathrm{p} \\
<0.05\end{array}$ & & \\
\hline $\begin{array}{l}\text { CbE- } \\
\text { SC }\end{array}$ & & & $\begin{array}{l}0.86, p< \\
0.05\end{array}$ & & & & & & \\
\hline $\begin{array}{l}\text { BChE- } \\
\text { B }\end{array}$ & & & & & & & $\begin{array}{l}0.82, \mathrm{p} \\
<0.05\end{array}$ & & \\
\hline $\begin{array}{l}\text { BChE- } \\
\text { SC }\end{array}$ & & & & & $\begin{array}{l}0.88, p< \\
0.05\end{array}$ & & & & \\
\hline $\begin{array}{l}\text { GABA- } \\
\text { SC }\end{array}$ & & & & & & & & $\begin{array}{l}-0.90, \mathrm{p} \\
<0.05\end{array}$ & \\
\hline $\begin{array}{l}\Delta \Psi \mathrm{m}- \\
\mathrm{B}\end{array}$ & & & & & & & $\begin{array}{l}0.91, p \\
<0.01\end{array}$ & $\begin{array}{l}-0.82, \mathrm{p} \\
<0.05\end{array}$ & \\
\hline \multicolumn{10}{|c|}{$0.1 \mu \mathrm{g} / \mathrm{kg}$} \\
\hline PP & & & & & & & & $\begin{array}{l}0.93, p< \\
0.01\end{array}$ & $\begin{array}{l}0.84, p< \\
0.05\end{array}$ \\
\hline $\begin{array}{l}\text { AChE- } \\
\text { B }\end{array}$ & & $\begin{array}{l}0.81, p< \\
0.05\end{array}$ & & $\begin{array}{l}0.87, \mathrm{p} \\
<0.05\end{array}$ & & & & & \\
\hline $\begin{array}{l}\text { AChE- } \\
\text { SC }\end{array}$ & & & & & & & & & $\begin{array}{l}-0.84, p< \\
0.05\end{array}$ \\
\hline CbE-B & & & $\begin{array}{l}0.94, p< \\
0.01\end{array}$ & & $\begin{array}{l}0.94, p< \\
0.01\end{array}$ & & & & \\
\hline
\end{tabular}

B: Brain. SC: Spinal cord. PP: PP1/PP2A activity. AChE: Acetylcholinesterase activity. CbE: Carboxyl esterase activities. BChE: Butyryl cholinesterase activity. GABA: $\gamma$-aminobutyric acid levels. $\triangle \Psi \mathrm{m}$ : Mitochondrial membrane potential. $\mathrm{Ca}^{+2}$ : Mitochondrial calcium. 


\begin{tabular}{|c|c|c|c|c|c|c|c|c|c|}
\hline & CbE-SC & BChE-B & BChE-SC & GABA-B & $\begin{array}{l}\text { GABA- } \\
\text { SC }\end{array}$ & $\Delta \Psi \mathrm{m}-\mathrm{B}$ & $\begin{array}{l}\Delta \Psi \mathrm{m}- \\
\mathrm{sC}\end{array}$ & $\mathrm{Ca}^{+2}-\mathrm{B}$ & $\mathrm{Ca}^{+2}-\mathrm{SC}$ \\
\hline $\begin{array}{l}\text { CbE- } \\
\text { SC }\end{array}$ & & & $\begin{array}{l}0.83, p< \\
0.05\end{array}$ & $\begin{array}{l}-0.86, p \\
<0.05\end{array}$ & $\begin{array}{l}0.93, p< \\
0.01\end{array}$ & & & & \\
\hline \multicolumn{10}{|l|}{$\begin{array}{l}\text { BChE- } \\
B\end{array}$} \\
\hline \multicolumn{10}{|l|}{$\begin{array}{l}\text { BChE- } \\
\text { SC }\end{array}$} \\
\hline & & & & & $\begin{array}{l}0.91, p< \\
0.05\end{array}$ & $\begin{array}{l}-0.84, p \\
<0.05\end{array}$ & & & \\
\hline \multicolumn{10}{|c|}{$1.0 \mu \mathrm{g} / \mathrm{kg}$} \\
\hline \multicolumn{10}{|l|}{ PP } \\
\hline $\begin{array}{l}\text { AChE- } \\
B\end{array}$ & & $\begin{array}{l}0.93, p< \\
0.05\end{array}$ & & & & & $\begin{array}{l}-0.95, p \\
<0.05\end{array}$ & & \\
\hline $\begin{array}{l}\text { AChE- } \\
\text { SC }\end{array}$ & $\begin{array}{l}0.96, \mathrm{p} \\
<0.01\end{array}$ & & $\begin{array}{l}0.98, p< \\
0.01\end{array}$ & $\begin{array}{l}0.99, p \\
<0.01\end{array}$ & $\begin{array}{l}0.99, p< \\
0.001\end{array}$ & & & & $\begin{array}{l}0.94, p< \\
0.05\end{array}$ \\
\hline CbE-B & & $\begin{array}{l}0.98, p< \\
0.01\end{array}$ & & & & $\begin{array}{l}-0.90, p \\
<0.05\end{array}$ & & & $\begin{array}{l}0.90, p< \\
0.05\end{array}$ \\
\hline $\begin{array}{l}\text { CbE- } \\
\text { SC }\end{array}$ & & & $\begin{array}{l}0.99, p< \\
0.001\end{array}$ & $\begin{array}{l}0.90, p \\
<0.05\end{array}$ & $\begin{array}{l}0.98, p< \\
0.01\end{array}$ & $\begin{array}{l}-0.88, p \\
<0.05\end{array}$ & & & $\begin{array}{l}0.98, p< \\
0.01\end{array}$ \\
\hline \multicolumn{10}{|l|}{$\begin{array}{l}\text { BChE- } \\
B\end{array}$} \\
\hline $\begin{array}{l}\text { BChE- } \\
\text { SC }\end{array}$ & & & & $\begin{array}{l}0.94, p \\
<0.05\end{array}$ & $\begin{array}{l}1.00, p< \\
0.001\end{array}$ & $\begin{array}{l}-0.91, \mathrm{p} \\
<0.05\end{array}$ & & & $\begin{array}{l}0.99, \mathrm{p}< \\
0.001\end{array}$ \\
\hline${ }_{B}^{\text {GABA- }}$ & & & & & $\begin{array}{l}0.97, p< \\
0.01\end{array}$ & & & & $\begin{array}{l}0.90, p< \\
0.05\end{array}$ \\
\hline $\begin{array}{l}\text { GABA- } \\
\text { SC }\end{array}$ & & & & & & $\begin{array}{l}-0.91, \mathrm{p} \\
<0.05\end{array}$ & & & $\begin{array}{l}0.98, p< \\
0.01\end{array}$ \\
\hline${ }_{B} \Psi_{m}-$ & & & & & & & & & $\begin{array}{l}-0.96, p< \\
0.05\end{array}$ \\
\hline$\frac{\Delta \Psi \mathrm{m}-}{\mathrm{SC}}$ & & & & & & & & $\begin{array}{l}0.89, p< \\
0.05\end{array}$ & \\
\hline $\begin{array}{l}\text { B: Brair } \\
\text { activiti } \\
\text { potenti }\end{array}$ & $\begin{array}{l}\text { C: Spina } \\
\text { 3ChE: B } \\
C^{+2}: \mathrm{Mi}\end{array}$ & $\begin{array}{l}\text { rd. PP: } \\
\text { l. cholir } \\
\text { hondrial }\end{array}$ & $\begin{array}{l}\text { PP2A act } \\
\text { rase activ } \\
\text { ium. }\end{array}$ & $\begin{array}{l}\text { ity. AChE: } \\
\text { y. GABA: }\end{array}$ & $\begin{array}{l}\text { cetylcholin } \\
\text { minobuty }\end{array}$ & $\begin{array}{l}\text { terase act } \\
\text { acid level }\end{array}$ & $\begin{array}{l}\text { tiy. CbE: } \\
\Delta \Psi_{\mathrm{m}}: \mathrm{M}\end{array}$ & $\begin{array}{l}\text { poxyl este } \\
\text { hondrial } n\end{array}$ & $\begin{array}{l}\text { se } \\
\text { mbrane }\end{array}$ \\
\hline
\end{tabular}

In treated groups, the number of relationships increased with the level of toxins (Tables 1 and 2). However, due to the higher number of correlations and their consistency with IBRv2, it is worth emphasising the findings observed with 10.0 $\mu \mathrm{g} / \mathrm{L}$ of $\mathrm{MaE}$ and $1.0 \mu \mathrm{g} / \mathrm{kg} \mathrm{NCTD}$.

In the brain of fish exposed to $\mathrm{MaE}, \mathrm{BChE}$ was related with $\mathrm{AChE}$; also reduced number of correlations among enzymes involved in neurotransmission in the spinal cord was detected. BChe was positively related with $\mathrm{AChE}$ and $\mathrm{CbE}$, and $\mathrm{CbE}$ 
with AChE. In thebrain, BChE displayed statistical correlations with AChE and CbE. GABA levels in the brain and spinal cord showed positive and significant links with $\mathrm{AChE}, \mathrm{CbE}$, and $\mathrm{BChE}$ in the spinal cord, as was the case for GABA in the spinal cord with the same neurotransmitter in the brain. Nonetheless, the number of relationships of mitochondrial performance with esterases and neurotransmitters increased. $\Delta \Psi \mathrm{m}$ evaluated as mean fluorescence intensity in the brain was inversely related with $\mathrm{CbE}$ in the brain and spinal cord, BChE in the spinal cord, and GABA in the brain. In the case of $\Delta \Psi_{\mathrm{m}}$ in the spinal cord, only an inverse relationship with AChE in the brain was noted. In addition, $\Delta \Psi_{\mathrm{m}}$ in the spinal cord was related to brain $\mathrm{mCa}^{+2}$. Despite these interesting findings, the higher number of statistical correlations occurred among $\mathrm{mCa}^{+2}$ in the spinal cord with neurotoxicity biomarkers. We found positive correlations with spinal cord $\mathrm{AChE}$, spinal cord $\mathrm{CbE}$ and $\mathrm{BChE}$ activities, brain $\mathrm{CbE}$, and GABA in the brain and spinal cord. A negative correlation was found with $\Delta \Psi_{m}$ in the brain (Table 1).

The results from fish exposed to the to high doses of NCTD $(1.0 \mu \mathrm{g} / \mathrm{kg})$ demonstrated a positive correlation in a dosedependent manner of the three enzymes involved in neurotransmission among the brain and spinal cord and vice versa, contrary to what was observed in the control group, where only one positive relationship was found. Remarkably, the levels of GABA in the brain and spinal cord were positively related with $\mathrm{AChE}, \mathrm{CbE}$, and BChE activities in the spinal cord. However, brain $\triangle \Psi \mathrm{m}$ was negatively correlated with $\mathrm{CbE}$ in the brain and spinal cord, in addition to BChE and with GABA levels in the spinal cord. In contrast, $\Delta \Psi_{\mathrm{m}}$ in the spinal cord only indicated a negative relationship with $\mathrm{AChE}$ in the brain. However, a great number of correlations were found between $\mathrm{mCa}^{+2}$ in the spinal cord and the enzymes involved in neurotransmission and with levels of GABA in both organs studied. However, this biomarker showed a negative relationship with $\Delta \Psi_{\mathrm{m}}$ in the brain and was not linked with $A C h E$ and $B C h E$ in the brain, $\Delta \Psi \mathrm{m}$ in the spinal cord, or PP1/PP2A in the liver (Table 2).

\section{Discussion}

In this study, it is not suprising as in other studies in fish species that some the main effect of MCs in the liver of Oreochromis niloticus was the enzymatic inhibition of protein phosphatases such as the PP1/PP2A isoforms. However, the interesting aspect is probably its relationships with the functionality of the nervous system. The inhibition of PP1/PP2A by MCs has been widely studied in mammals an fish species'since it has a high degree of specificity towards these enzymes (e.g. Toivola et al. 1994; Carbis et al. 1997; Landsberg 2002; Mezhoud et al. 2008). Similar toxic responses have been documented for the specific inhibitor of PP1/PP2A activity, norcantharidin, using in vitro and in vivo mammal models (Hill et al. 2008; Deng et al. 2013; Wang et al. 2018). The MCs and NCDT have been recognized as inhibitors of protein phosphatase 2A through their binding with the catalytic subunit of this enzyme (Liu and Sun 2015; Tang et al. 2016; Fontanillo and Köhn 2018; Wang et al. 2018). Similarly, MCs and NCDT are able also to inhibit the activity of the ubiquitous Ser/Thr protein phosphatase 1 (PP1) (Liu and Sun 2015; Tang et al. 2016; Fontanillo and Köhn 2018; Wang et al. 2018). The PP1 regulates diverse and essential cellular processes such as cell cycle progression, protein synthesis, muscle contraction, carbohydrate metabolism, transcription, and neuronal signalling (Liang et al. 2011). On the other hand, PP2A is one of the most complex members of the PP family; it is responsible for regulating physiological processes such as neuronal stabilization by ion exchange, cardiac muscle function, and cell cycle (Lires et al. 2008). In addition, the PPs are very important in regulating $\mathrm{Ca}^{+2}$ channels in neurons through the cGMP dependent signalling pathway (Zsombok et al. 2005). However, much less is understood about whether and how a particular type of PP contributes to regulating neuronal $\mathrm{Ca}^{+2}$ channel activities. Despite the wide involvement of PP1/PP2A in the regulation of anionic channels,our results do not contribute in a great way to solving this question, particularly in fish exposed to MaE. However, the in vitro and in vivo terrestrial models provided specific clues about the neurotoxicity, which the MCs entail. This toxic response is due to the ability of MCs to cross the blood-brain barrier and most neural cells through OATPs, therefore the $\mathrm{Ca}^{+2}$ levels increase and could induce apoptosis (Hinojosa et al. 2019). Specifically, in SH-SY5Y cells and rat hippocampus, it has been shown that MC-LR increased the demethylation of

Page $12 / 24$ 
PP2Ac, which was accompanied by associated rises in GSK-3 $\beta$ phosphorylation at Ser9. As a consequence, the tau hyperphosphorylation at PP2A-favorable sites occurred (Zhang et al. 2018). Based on previous reports, it has been proposed that the neurotoxicity of MCs is also related with cytoskeleton disruption in nervous system cells (Hinojosa et al. 2019). In contrast, in the brain and spinal cord of the Nile tilapia treated with the intermediate NCTD dose, statistical relationships between $\mathrm{mCa}^{+2}$ in the brain and spinal cord and PP1/PP2A activity were observed. These results would be promising to further investigate and suggest a highly specific saturable process, probably related to an increase in $\mathrm{mCa}^{+2}$ levels and also with inhibition of PP2A activity in a dose-dependent manner.

Notwithstanding, we do not normalized the MaE exposure with the basis on MC-YR or MC-RR levels, it has been documented that MC-YR sligly increase of movement in zebrafish embryos (Jonas et al. 2015), whereas MC-RR alter the oxidative stress response (Cazenave et al. 2006) and modifyed the swimming activity of Jenynsia multidentata (Cazenave et al. 2008). However, taking into account the sanitary importance of MC-LR as well as at environmental level, the relevance of MC-LR able to induce neurotoxic effects stands out (Hinojosa et al. 2019).

In this study, we observed changes directly related to the activity of enzymes involved in neurotransmission, as well as the $\triangle \Psi \mathrm{m}$ and $\mathrm{mCa}^{+2}$ with exposure to MCs and NCTD. The results obtained for $\mathrm{mCa}^{+2}$ levels were different for NCTD and MCs exposures; however, the star plot areas obtained from IBRv2 showed a similar tendency in the damage of the CNS of the Nile tilapia. It is well known that any changes in $\mathrm{mCa}^{+2}$ levels cause alterations in membrane potential since both variables are closely related, altering in this way the mitochondrial function or cation accumulation. The increase of $\mathrm{mCa}^{+2}$ levels can augment ATP production by altering the activity of calcium-sensitive mitochondrial matrix enzymes. Medium and high concentration of MCs do not increase calcium levels in the mitochondria, which may be because the calcium channels are open. However, the release of calcium from the mitochondria could be related to the necro-apoptosis processes (Bai et al. 2013). On the other hand, intracellular deposits of this cation activates calcium channels, a response named Store-Operated Calcium Channels (SOCs) (Stathopulos and Ikura 2017). The SOCs are a nearly ubiquitous $\mathrm{Ca}^{+2}$ entry pathway stimulated by numerous cell surface receptors via the reduction of $\mathrm{Ca}^{+2}$ concentration in the endoplasmic reticulum (ER). The defining feature of SOCs that distinguishes them from all other classes of $\mathrm{Ca}^{+2}$ channels, is their activation by the reduction of $\mathrm{Ca}^{+2}$ concentration in the lumen of the ER. It is worth mentioning that, at the neuronal level, changes in calcium channels can promote the fusion of the synaptic vesicle membrane with the axon terminal membrane in the neurons, which causes the release of ACh to the synaptic cleft by an exocytosis mechanism (Parekh and Putney 2005; Prakriya and Lewis 2005; Lewis 2011; Kawamoto et al. 2012; Finkel et al. 2015). This relationship between $\mathrm{mCa}+2$ levels and AChE levelswas significantly evident in the spinal cord of the Nile tilapia treated with $\mathrm{MaE}$ and in the brain and spinal cord of fish dosed with NCTD. In this regard, when ACh enters to the synaptic cleft, it can bind to cholinergic receptors, whose binding occurs quickly occurs due to the neurotransmitter being rapidly metabolised by AChE. As a consequence, the activity of AChE, and probably BChE and CbE, is affected, promoting the presence of AChE and the synthesis of BChE after exposures to MCs as noted in the current study, as well as in fish treated with NCTD, by increasing the relationships between $\mathrm{mCa}^{+2}$ with these enzymes involved in neurotransmission. Likewise, it is possible that decreases in $\Delta \Psi_{\mathrm{m}}$, in addition to $\mathrm{Ca}^{+2}$ levels, influenced the neuronal response in addition to the flexibility of $\mathrm{Ca}^{+2}$ signalling by modifying the cytosolic $\mathrm{Ca}^{+2}$ concentrations via a regulated opening of the cellular membrane and subcellular $\mathrm{Ca}^{+2}$ sensitive channels as documented in the brain by Kawamoto et al. (2012). However, the findings of IBRv2 denote that the activity of BChE and AChE seems to be unaltered regarding the controls, in contrast to that observed with the activity of $\mathrm{CbE}$. This response suggests that hydrolysis and esterification of other substrates (Perry et al. 2011) could be affected by exposure to MaE and NCDT, as well as the high substrate-specificity of AChE and BChE. 
Proteomic analysis showed seventeen proteins were involved in the response to MC-LR treatment, eight of them were to be reported as being directly related with MC-LR effects: fumarylacetoacetase (EC 3.7.1.2), protein disulfide-isomerase A4 and A6, 78 kDa glucose-regulated protein homolog, 40S ribosomal protein SA (EC 2.3.1.267 - [ribosomal protein S5]alanine N-acetyltransferase), prohibitin (EC 6.4.1.1 - pyruvate carboxylase), cytochrome b5, and ATP synthase mitochondrial d subunit (Hubbard and McHugh 1996; Mikhailov et al. 2003; Malécot et al. 2009). The last five are directly related to ATP generation in the mitochondria. Moreover, the concentrations of $\mathrm{Ca}^{+2}$ tend to equalise on both sides of the cell membrane producing depolarisation and causing changes in the permeability of the membrane allowing the influx of others divalent ions (Hubbard and McHugh 1996). About the topic, we fond negative relationships between $\Delta \Psi \mathrm{m}$ in the brain and $\mathrm{mCa}^{+2}$ levels in the spinal cord, and positive dealings between $\Delta \Psi_{\mathrm{m}}$ in the spinal cord and $\mathrm{mCa}^{+2}$ levels in the brain of Nile tilapia treated with the higher concentration of $\mathrm{MaE}$ and in the higher dose of NCTD. This response suggests that the generation of a proton gradient through the mitochondrial membrane was modified, altering in this way the release of neurotransmitters evaluated through the activity of the enzymes involved in their metabolism. However, the control of this process was maintained in the but not the spinal cord'despite the proton gradient alterations elicited by MaE and NCTD.

In addition to variations in levels of $\mathrm{AChE}, \mathrm{BChE}$, and $\mathrm{CbE}$, the inhibitory neurotransmitter of the $\mathrm{CNS}$, $\mathrm{Y}$-aminobutyric acid (GABA) was evaluated. Approximately $20 \%$ of all neurons in the nervous system have GABA as a neurotransmitter, which prevents CNS overexcitation (Bak et al. 2006; Kalueff and Nutt 2007). Our results showed positive relationships of GABA levels in the brain and spinal cord with $\mathrm{mCa}^{+2}$ levels in the spinal cord. In addition, GABA in the brain and spinal cord was positively related with the inhibition of $\mathrm{AChE}, \mathrm{BChE}$, and $\mathrm{CbE}$ on the organs in fish treated with MaE and also with the same enzymes in the spinal cord of fish dosed with NCTD. These results clearly indicate post-synaptic alterations able to induce disruption of GABA-binding with its receptor, leading an over-excitation of CNS cells.

To our knowledge, previous studies about these responses are not available in fish exposed to MaE and NCTD; however, this study has opened up new opportunities'to explore more consequences of eutrophication process, particularly in fish species exposed to MCs linked with blooms of some Microcystis aeruginosa strains.

\section{Concluding Remarks}

In summary, alterations in calcium levels are intimately intertwined with ion exchange; therefore, inhibition of phosphatases, as well as alterations in mitochondrial calcium levels, cause disruptions in neurotransmission by modifications of transporters of ATP-dependent ions. These effects related with the eutrophication process can be evaluated by the neurotoxicity biomarkers studied in the present work.

\section{Declarations}

\section{Author contributions}

MNM, GGLH, and JPRL conducted experiments, MNM, MLDL, EAGL and AVL designed experiments, and interpreted results, AVL wrote the manuscript.

\section{Ethics Standards}

The study was performed in agreement with Article 38 and Chapter V of the Directive 2010/63/EU of the European Parliament and of the Council of 22 September 2010 for the protection of animals used for scientific purposes (https://eur-lex.europa.eu/legal-content/EN/TXT/?uri=celex\%3A32010L0063) 
No potential competing interest was reported by the authors.

\section{Funding and Acknowledgements}

This study was supported by Instituto Politécnico Nacional SIP code 20180917 and SIP code 20201044. M. NajeraMartínez is a graduate DSc in Chemobiological Sciences which received finantial support by a postdoctoral fellowship granted by CONACyT, México. G.G. Landon-Hernández is a graduate BSc student. J.P. Romero-López is a graduate DSc in Chemobiological Sciences who received scholarship from CONACyT and BEIFI-IPN. M.L. Domínguez-López. E.A. García-Latorre and A. Vega-López are fellow of Estímulos al Desempeño en Investigación and Comisión y Fomento de Actividades Académicas (Instituto Politécnico Nacional) and Sistema Nacional de Investigadores (SNI, CONACyT, México).

\section{References}

Baganz D, Staaks G, Steinberg C (1998) Impact of the cyanobacteria toxin, microcystin-Ir on behaviour of zebrafish, Danio rerio. Water Res. 32(3):948-952. https://doi.org/10.1016/S0043-1354(97)00207-8

Baganz D, Staaks G, Pflugmacher S, Steinberg CEW (2004) A comparative study on microcystin-LR induced behavioural changes of two fish species (Danio rerio and Leucaspius delineatus). Environ. Toxicol. 19:564-570.

https://doi.org/10.1002/tox.20063

Bai T, Dong DS, Pei L (2013) Resveratrol Mitigates Isoflurane-Induced Neuroapoptosis by Inhibiting the Activation of the Akt-regulated Mitochondrial Apoptotic Signaling Pathway. Int J Mol Med 32(4):819-26.

https://doi.org/10.3892/ijmm.2013.1464

Bak LK, Schousboe A, Waagepetersen HS (2006) The glutamate/GABA-glutamine cycle: aspects of transport, neurotransmitter homeostasis and ammonia transfer. J Neurochem 98(3):641-53. https://doi.org/10.1111/j.14714159.2006.03913.x

Carbis CR, Rawlin GT, Grant P, Mitchell GF, Anderson JW, McCauley I (1997) A study of fetal carp, Cyprinus carpio L., exposed to Microcystis aeruginosa at Lake Mokoan, Australia, and possible implications for fish health. J Fish Dis 20:81-91. https://doi.org/10.1046/j.1365-2761.1997.d01-111.x

Carmichael WW, Azevedo SMFO, An JS, Molica, RJR, Jochimsen EM, Lau S, Rinehart, KL, Shaw GR, Eaglesham, GK (2001) Human fatalities from cyanobacteria: Chemical and biological evidence for cyanotoxins. Environ Health Perspect 109(7):663-8. https://doi.org/10.1289/ehp.01109663

Cazenave J, Bistoni MA, Pesce SB, Wunderlin DA (2006) Differential detoxification and antioxidant response in diverse organs of Corydoras paleatus experimentally exposed to microcystin-RR. Aquat Toxicol. 76(1):1-12.

https://doi.org/10.1016/j.aquatox.2005.08.011

Cazenave J, Nores ML, Miceli M, Díaz MP, Wunderlin DA, Bistoni MA (2008) Changes in the swimming activity and the glutathione S-transferase activity of Jenynsia multidentata fed with microcystin-RR. Water Res 42(4-5):1299-307. https://doi.org/10.1016/j.watres.2007.09.025

Chang H, Huang H, Huang T, Yang P, Wang Y, Juan H (2013) Flow Cytometric Detection of Mitochondrial Membrane Potential. Bio-protocol 3(8):e430. https://doi.org/10.21769/BioProtoc.430 
Chorus I, Bartram J (1999) Toxic cyanobacteria in water: a guide to their public health consequences, monitoring and management/edited by Ingrid Chorus and Jamie Bertram. World Health Organization.

https://apps.who.int/iris/handle/10665/42827

Deng L, Dong J, Wang W (2013) Exploiting protein phosphatase inhibitors based on cantharidin analogues for cancer drug discovery. Mini Rev Med Chem 13(8):1166-76. https://doi.org/10.2174/1389557511313080005

Dzul-Caamal R, Salazar-Coria L, Olivares-Rubio HF, Rocha-Gómez MA, Girón-Pérez MI, Vega-López A (2016) Oxidative stress response in the skin mucus layer of Goodea gracilis (Hubbs and Turner, 1939) exposed to crude oil: A noninvasive approach. Comp Biochem Physiol A Mol Integr Physiol 200:9-20. https://doi.org/10.1016/j.cbpa.2016.05.008

Finkel T, Menazza S, Holmström KM, Parks RJ, Liu J, Sun J, Liu J, Pan X, Murphy E (2015) The ins and outs of mitochondrial calcium. Circ Res 116(11):1810-9. https://doi.org/10.1161/CIRCRESAHA.116.305484

Fontanillo M, Köhn M (2018) Microcystins: Synthesis and structure-activity relationship studies toward PP1 and PP2A. Bioorg Med Chem 26(6):1118-1126. https://doi.org/10.1016/j.bmc.2017.08.040

Frezza C, Cipolat S, Scorrano L (2007) Organelle isolation: functional mitochondria from mouse liver, muscle and cultured filroblasts. Nat Protoc 2(2):287-295. https://doi.org/10.1038/nprot.2006.478

Gélinas M, Juneau P, Gagné F (2012) Early biochemical effects of Microcystis aeruginosa extracts on juvenile rainbow trout (Oncorhynchus mykiss). Comp Biochem Physiol B Biochem Mol Biol. 161(3):261-7.

https://doi.org/10.1016/j.cbpb.2011.12.002

Guillard RRL (1975) Culture of phytoplankton for feeding marine invertebrates, in: Smith, W.L., Chanley, M.H. (Eds.) Culture of Marine Invertebrate Animals. Plenum Press, New York 26-60

Guiry in Guiry MD, Guiry GM (2020) AlgaeBase. World-wide electronic publication, National University of Ireland, Galway. Available on http://www.algaebase.org/search/species/detail/?species_id=30050

Gupta N, Pant SC, Vijayaraghavan R, Rao PVL (2003) Comparative toxicity evaluation of cyanobacterial cyclic peptide toxin microcystin variants (LR, RR, YR) in mice. Toxicology 188:285-296. https://doi.org/10.1016/s0300-

$483 \times(03) 00112-4$

Harada KI, Tsuji K (1998) Persistence and Decomposition of Hepatotoxic Microcystins Produced by Cyanobacteria in Natural Environment. Journal of Toxicology: Toxin Reviews 17(3):385-403.

https://doi.org/10.3109/15569549809040400

Hestrin N (1949) The reaction of acetylcholine and other carboxylic acid derivatives with hydroxylamine, and its analytical application. J Biol Chem 180(1):249-61.

Hill TA, Stewart SG, Gordon CP, Ackland SP, Gilbert J, Sauer B, Sakoff JA, McCluskey A (2008) Norcantharidin analogues: synthesis, anticancer activity and protein phosphatase 1 and 2A inhibition. Chem Med Chem 3(12):1878-92. https://doi.org/10.1002/cmdc.200800192

Hinojosa MG, Gutiérrez-Praena D, Prieto Al, Guzmán-Guillén R, Jos A, Cameán AM (2019) Neurotoxicity induced by microcystins and cylindrospermopsin: A review. Sci Total Environ 10 (668):547-565.

https://doi.org//10.1016/j.scitotenv.2019.02.426 
Hotta Y, Ezaki S, Atomi H, Imanaka T (2002) Extremely stable and versatile carboxylesterase from a hyperthermophilic archaeon. Appl Environ Microbiol 68(8):3925-31. https://doi.org//10.1128/AEM.68.8.3925-3931.2002

Hubbard MJ, McHugh NJ (1996) Mitochondrial ATP synthase F1- $\beta$-subunit is a calcium-binding protein. FEBS Letters 391(3):323-329. https://doi.org/10.1016/0014-5793(96)00767-3

Jonas A, Scholz S, Fetter E, Sychrova E, Novakova K, Ortmann J, Benisek M, Adamovsky O, Giesy JP, Hilscherova K (2015) Endocrine, teratogenic and neurotoxic effects of cyanobacteria detected by cellular in vitro and zebrafish embryos assays. Chemosphere. 120: 321-7. https://doi.org/10.1016/j.chemosphere.2014.07.074

Kalueff AV, Nutt DJ (2007) Role of GABA in anxiety and depression. Depress Anxiety 24(7): 495-517. https://doi.org//10.1002/da.20262

Kataoka M, Fukura Y, Shinohara Y, Baba Y (2005) Analysis of mitochondrial membrane potential in the cells by microchip flow cytometry. Electrophoresis 26(15):3025-31. https://doi.org/10.1002/elps.200410402

Kawamoto EM, Vivar C, Camandola S (2012) Physiology and pathology of calcium signaling in the brain. Front Pharmacol 3(61). https://doi.org/10.3389/fphar.2012.00061

Kist LW, Rosemberg DB, Pereira TC, de Azevedo MB, Richetti SK, de Castro Leão J, Yunes JS, Bonan CD, Bogo MR (2012) Microcystin-LR acute exposure increases AChE activity via transcriptional ache activation in zebrafish (Danio rerio) brain. Comp Biochem Physiol C Toxicol Pharmacol 155(2):247-52. https://doi.org/10.1016/j.cbpc.2011.09.002

Khuhawar MY, Rajper AD (2003) Liquid chromatographic determination of gamma-aminobutyric acid in cerebrospinal fluid using 2-hydroxynaphthaldehyde as derivatizing reagent. J Chromatogr B Analyt Technol Biomed Life Sci 788(2):413-8. https://doi.org/10.1016/s1570-0232(03)00062-x

Knedel M, Böttger R (1967) [A kinetic method for determination of the activity of pseudocholinesterase (acylcholine acyl-hydrolase 3.1.1.8.)] Klin Wochenschr 45(6):325-7. https://doi.org/10.1007/bf01747115

Komárek J, Anagnostidis K (2005) Süsswasserflora von Mitteleuropa. Cyanoprokaryota: 2. Teil/2nd Part: Oscillatoriales. Vol. 19. München: Elsevier Spektrum Akademischer Verlag.

Landsberg JH (2002) The effects of harmful algal blooms on aquatic organisms. Fish Sci 10: 113-390. https://doi.org/10.1080/20026491051695

Lewis RS (2011) Store-Operated Calcium Channels: New Perspectives on Mechanism and Function. Cold Spring Harb Perspect Biol 3:a0039701. https://doi.org/10.1101/cshperspect.a003970

Liang J, Li T, Zhang, YL, Guo ZL, Xu LH (2011) Effect of microcystin-LR on protein phosphatase 2A and its function in human amniotic epithelial cells. J Zhejiang Univ Sci B 12(12):951-960. https://doi.org/10.1631/jzus.B1100121

Lires-Deán M, Caramés B, Cillero-Pastor B, Galdo F, López-Armada M, Blanco FJ (2008) Anti-apoptotic effect of transforming growth factor- $\beta 1$ on human articular chondrocytes: role of protein phosphatase $2 \mathrm{~A}$. Osteoarthritis Cartilage 16(11):1370-1378. https://doi.org/10.1016/j.joca.2008.04.001

Liu J, Sun Y (2015) The role of PP2A-associated proteins and signal pathways in microcystin-LR toxicity. Toxicol Lett 236(1):1-7. https://doi.org/10.1016/j.toxlet.2015.04.010

Page $17 / 24$ 
Malbrouck C, Kestemont P (2006) Effects of microcystins on fish. Environmental and Chemistry 25(1):72-86. https://doi.org/10.1897/05-029r.1

Malécot M, Mezhoud K, Marie A, Praseuth D, Puiseux-Dao S, Edery M (2009) Proteomic study of the effects of microcystin-LR on organelle and membrane proteins in medaka fish liver. Aquat Toxicol 94(2):153-161. https://doi.org/10.1016/s0009-2797(02)00075-3

Mezhoud K, Praseuth D, Puiseux-Dao S, Francois J-C, Bernard C, Edery M (2008) Global quantitative analysis of protein expression and phosphorylation status in the liver of the medaka fish (Oryzias latipes) exposed to microcystin-LR I. Balneation study. Aquat Toxicol 86(2):166-75. https://doi.org/10.1016/j.aquatox.2007.10.010

Mikhailov A, Härmälä-Braskén AS, Hellman J, Meriluoto J, Eriksson JE (2003) Identification of ATP-synthase as a novel intracellular target for microcystin-LR. Chem Biol Interact 142(3):223-237. https://doi.org/10.1016/s00092797(02)00075-3

Olivares-Rubio HF, Martínez-Torres ML, Domínguez-López ML, García-Latorre E, Vega-López A (2013) Pro-oxidant and antioxidant responses in the liver and kidney of wild Goodea gracilis and their relation with halomethanes bioactivation. Fish Physiol Biochem 39(6):1603-17. https://doi.org/10.1007/s10695-013-9812-8.

Olivares-Rubio HF, Martínez-Torres ML, Nájera-Martínez M, Dzul-Caamal R, Domínguez-López ML, García-Latorre E, Vega-López A (2015) Biomarkers involved in energy metabolism and oxidative stress response in the liver of Goodea gracilis Hubbs and Turner, 1939 exposed to the microcystin-producing Microcystis aeruginosa LB85 strain. Environ Toxicol 30(10):1113-24. https://doi.org/10.1002/tox.21984

Qian H, Liu G, Lu T, Sun L (2018) Developmental neurotoxicity of Microcystis aeruginosa in the early life stages of zebrafish. Ecotoxicol Environ Saf. 151:35-41. https://doi.org//10.1016/j.ecoenv.2017.12.059

Parekh AB, Putney JW (2005) Store-operated calcium chan-nels. Physiol Rev 85:757-810. https://doi.org/10.1152/physrev.00057.2003

Perry SW, Norman JP, Barbieri J, Brown EB, Gelbard HA (2011) Mitochondrial membrane potential probes and the proton gradient: a practical usage guide. Biotechniques 50(2):98-115. https://doi.org/10.2144/000113610

Prakriya M, Lewis RS (2015) Store-Operated Calcium Channels. Physiol Rev 95(4):1383-1436.

https://doi.org/10.1152/physrev.00020.2014

Sanchez W, Burgeot T, Porcher J (2013) A novel "Integrated Biomarker Response" calculation based on reference deviation concept. Environ. Sci. Pollut. Res. 20: 2721-2725. https://doi.org/10.1007/s11356-012-1359-1

Silberman SR, Speth M, Nemani R, Ganapathi MK, Dombradi V, Paris H, Lee EY (1984) Isolation and characterization of rabbit skeletal muscle protein phosphatases C-I and C-II. J Biol Chem 259(5):2913-22.

Stathopulos PB, Ikura M (2017) Store Operated Calcium Entry: From Concept to Structural Mechanisms. Cell Calcium 63:3-7 https://doi.org/10.1016/j.ceca.2016.11.005

Tang ZB, Chen YZ, Zhao J, Guan XW, Bo YX, Chen SW, Hui L (2016) Conjugates of podophyllotoxin and norcantharidin

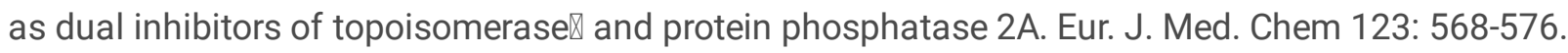

https://doi.org/10.1016/j.ejmech.2016.07.031 
Toivola DM, Erikssonb JE, Brautigan DL (1994) Identification of protein phosphatase 2A as the primary target for microcystin-LR in rat liver homogenates. FEBS Letters 344: 175-180. https://doi.org/10.1016/0014-5793(94)00382-3

Vega-López A, Pagadala NS, López-Tapia BP, Madera-Sandoval RL, Rosales-Cruz E, Nájera-Martínez M, ReyesMaldonado E (2019) Is related the hematopoietic stem cells differentiation in the Nile tilapia with GABA exposure? Fish Shellfish Immunol 93: 801-814. https://doi.org/10.1016/j.fsi.2019.08.032

Wang G, Dong J, Deng L (2018) Overview of cantharidin and its analogues. Curr Med Chem 25(17):2034-2044. https://doi.org/10.2174/0929867324666170414165253

Wiegand C, Pflugmacher S (2005) Ecotoxicological effects of selected cyanobacterial secondary metabolites a short review. Toxicology and Applied Pharmacology 203(3): 201-218. https://doi.org/10.1016/j.taap.2004.11.002

Wu Q, Yan W, Liu C, Li L, Yu L, Zhao S, Li G. (2016) Microcystin-LR exposure induces developmental neurotoxicity in zebrafish embryo. Environ Pollut 213:793-800. https://doi.org/10.1016/j.envpol.2016.03.048

Wu Q, Yan W, Cheng H, Liu C, Hung TC, Guo X, Li G (2017) Parental transfer of microcystin-LR induced transgenerational effects of developmental neurotoxicity in zebrafish offspring. Environ Pollut 231(Pt 1):471-478.

https://doi.org/10.1016/j.envpol.2017.08.038

Zhang Y, Zhang J, Wang E, Qian W, Fan Y, Feng Y, Yin H, Li Y, Wang Y, Yuan T (2018) Microcystin-Leucine-Arginine Induces Tau Pathology Through Ba Degradation via Protein Phosphatase 2A Demethylation and Associated Glycogen Synthase Kinase-3ß Phosphorylation. Toxicol Sci 162(2):475-487. https://doi.org/10.1093/toxsci/kfx271

Zsombok A, Schrofner S, Hermann A, Kerschbaum HH (2005) A cGMP-dependent cascade enhances an L-type-like Ca2+ current in identified snail neurons. Brain Res 1032(1-2):70-6. https://doi.org/10.1016/j.brainres.2004.11.003

\section{Figures}



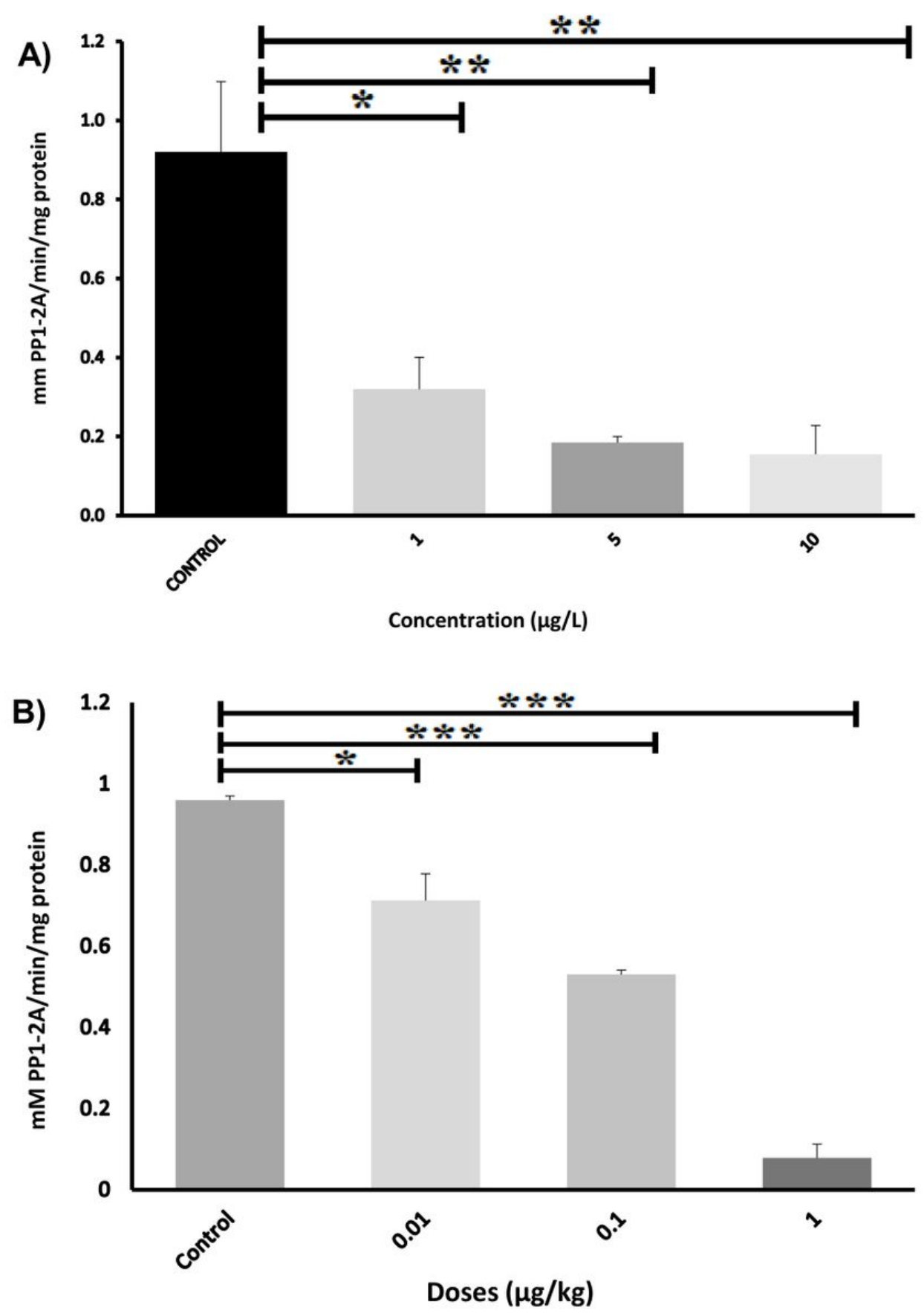

Figure 1

Activity of PP1/PP2A in the liver of the Nile tilapia (Oreochromis niloticus) treated with Microcystis aeruginosa extract $(A)$ and with norcantharidin (B). The bars represent the mean value and the bar errors represent the standard deviation. Biomarkers results were analysed by one-way analysis of variance (ANOVA) followed by Dunnet's Comparison Test, and statistical difference was set at ${ }^{*} \mathrm{p} \leq 0.05,{ }^{* \star} p \leq 0.01$, and ${ }^{* \star *} p \leq 0.001$. 

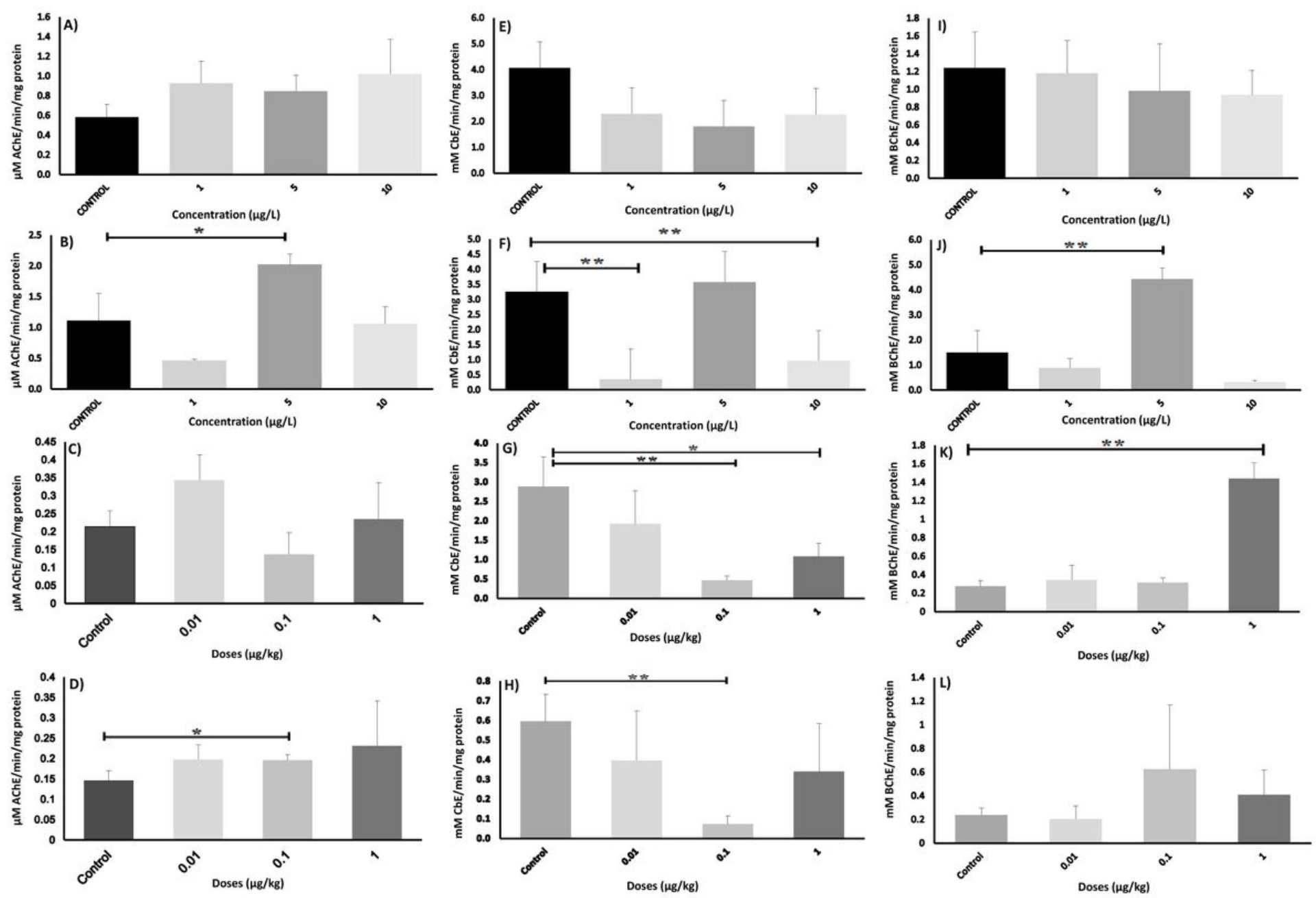

Figure 2

Activity of the enzymes involved in neurotransmission in the brain and spinal cord of the Nile tilapia (Oreochromis niloticus) treated with Microcystis aeruginosa extract (MaE) and with norcantharidine (NCTD). AChE in the brain (A) and spinal cord (B) of fish exposed to MaE. AChE in the brain (C) and spinal cord (D) of fish treated with NCTD. CbE in the brain (E) and spinal cord (F) of fish exposed to MaE. CbE in the brain (G) and spinal cord (H) of fish treated with NCTD. $\mathrm{BChE}$ in the brain (I) and spinal cord $(\mathrm{J})$ of fish exposed to MaE. BChE in the brain $(\mathrm{K})$ and spinal cord $(\mathrm{L})$ of fish treated with NCTD. The bars represent the mean value and the bar errors represent the standard deviation. Biomarkers results were analysed by one-way analysis of variance (ANOVA) followed by Dunnet's Comparison Test, and statistical difference was set at $* p \leq 0.05$ and ${ }^{*} p \leq 0.01$. 

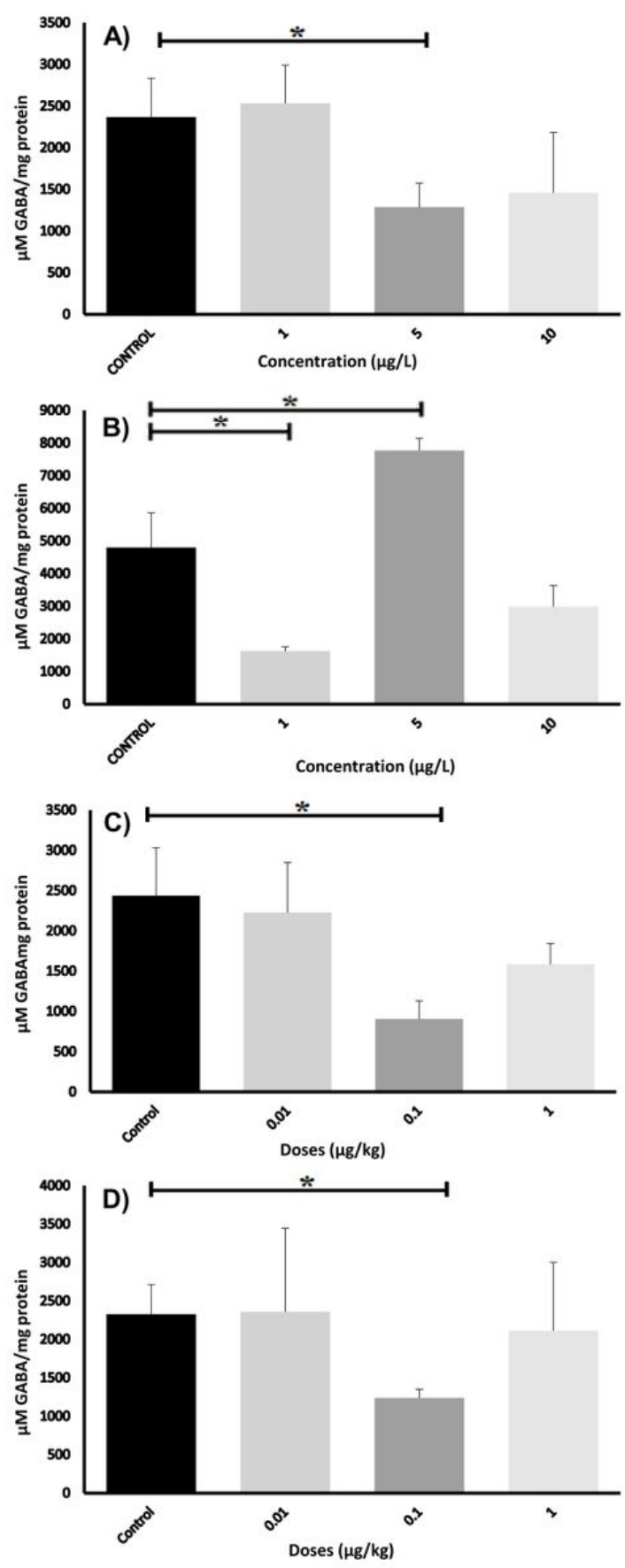

\section{Figure 3}

Levels of $Y$-aminobutyric acid (GABA) in the brain (A) and spinal cord (B) of the Nile tilapia (Oreochromis niloticus) treated with Microcystis aeruginosa extract (MaE) and with norcantharidine (NCTD) in the brain (C) and spinal cord (D). The bars represent the mean value and the bar errors represent the standard deviation. Biomarkers results were analysed by one-way analysis of variance (ANOVA) followed by Dunnet's Comparison Test, and statistical difference was set at * $\mathrm{p} \leq 0.05$. 

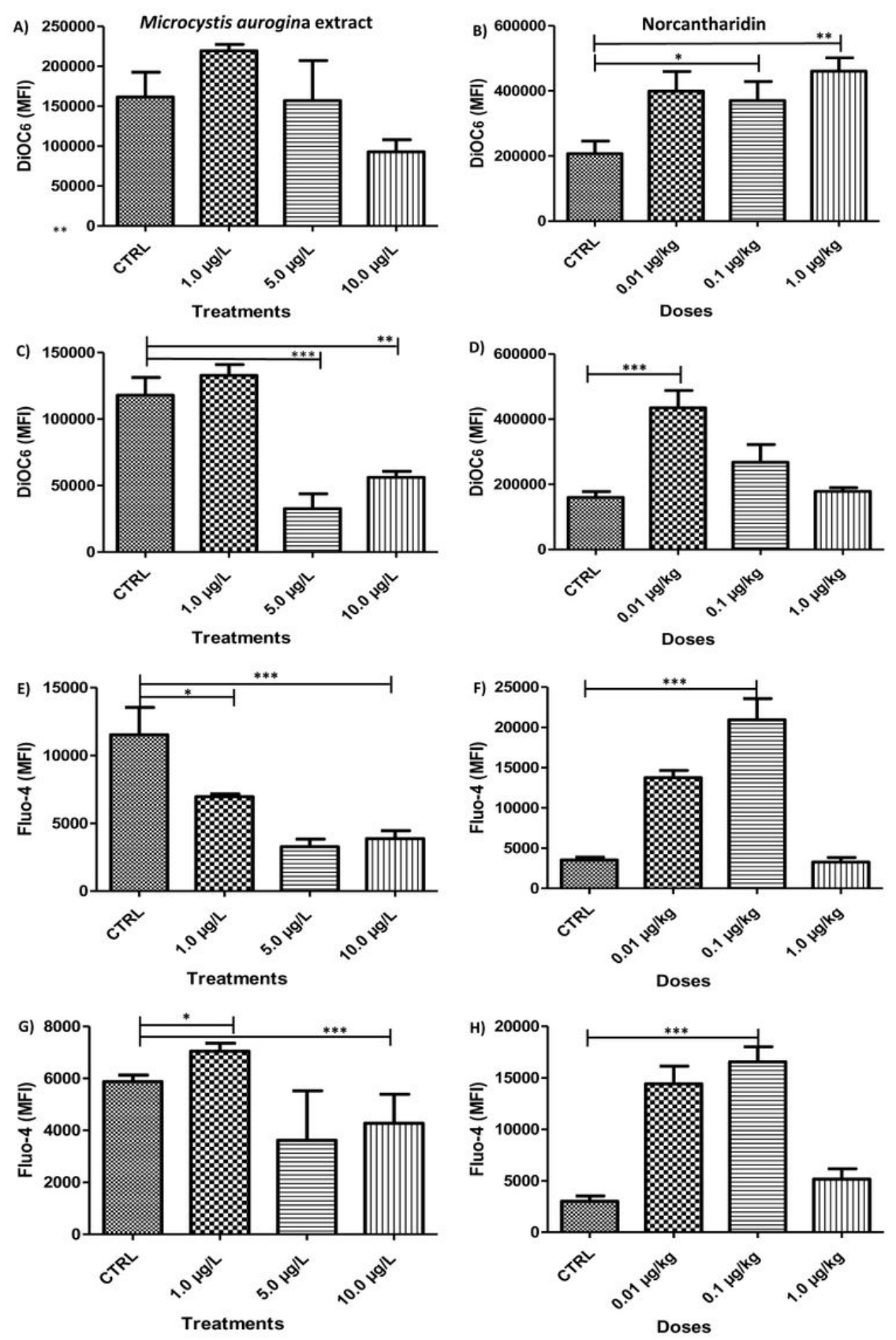

Figure 4

Mitochondrial membrane potential $(\Delta \Psi \mathrm{m})$ and mitochondrial $\mathrm{Ca}+2$ levels $(\mathrm{mCa}+2)$ in the brain and spinal cord of the Nile tilapia (Oreochromis niloticus) treated with Microcystis aeruginosa extract (left panels) and with norcantharidine (right panels). $\Delta \Psi_{\mathrm{m}}$ in the brain (A) and spinal cord (C) of fish treated with MaE. $\Delta \Psi_{\mathrm{m}}$ in the brain (B) and spinal cord (D) of fish dosed with NCTD. mCa+2 in the brain (E) and spinal cord (G) of fish treated with MaE. mCa+2 in the brain (F) and spinal cord $(\mathrm{H})$ of fish dosed with NCTD. The bars represent the mean value and the bar errors represent the standard deviation. Biomarkers results were analysed by one-way analysis of variance (ANOVA) followed by Dunnet's Comparison Test, and statistical difference was set at $* p \leq 0.05$, $* * p \leq 0.01$ and $* \star \star p \leq 0.001$. 


\section{Microcystis aeruginosa extract}
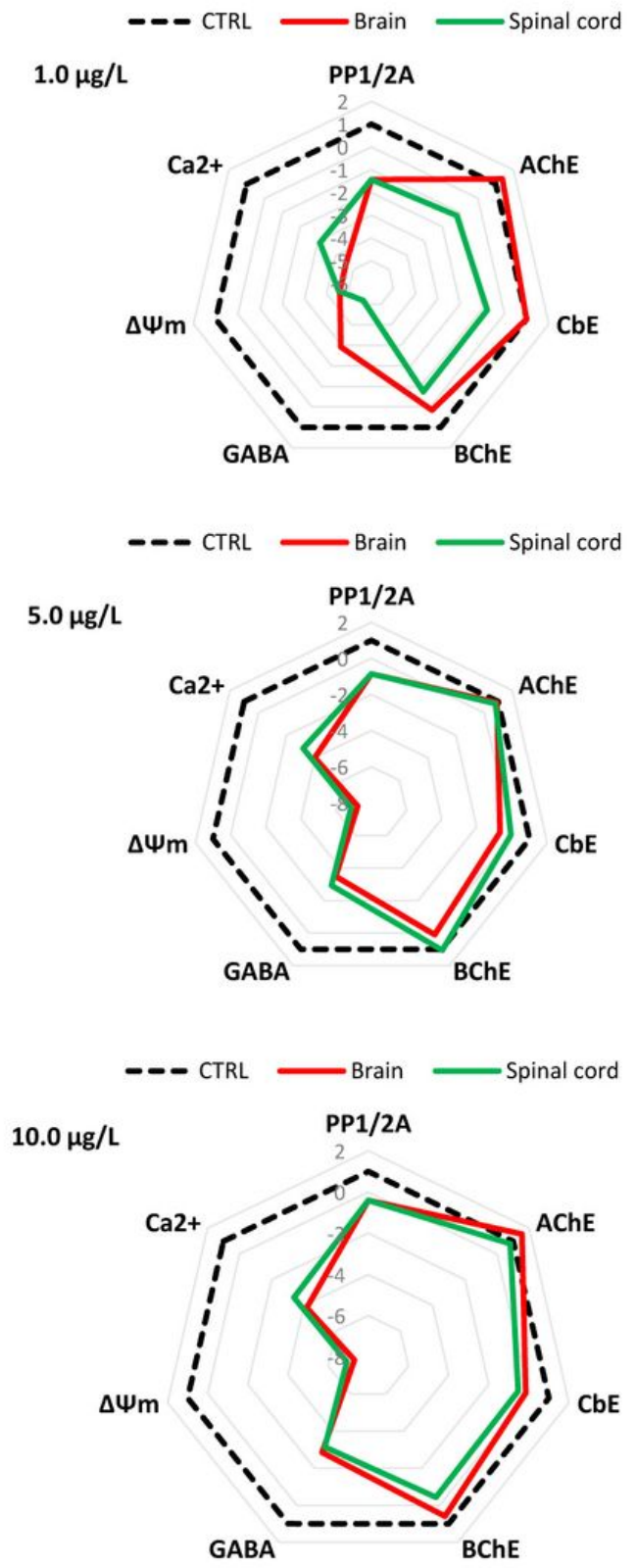
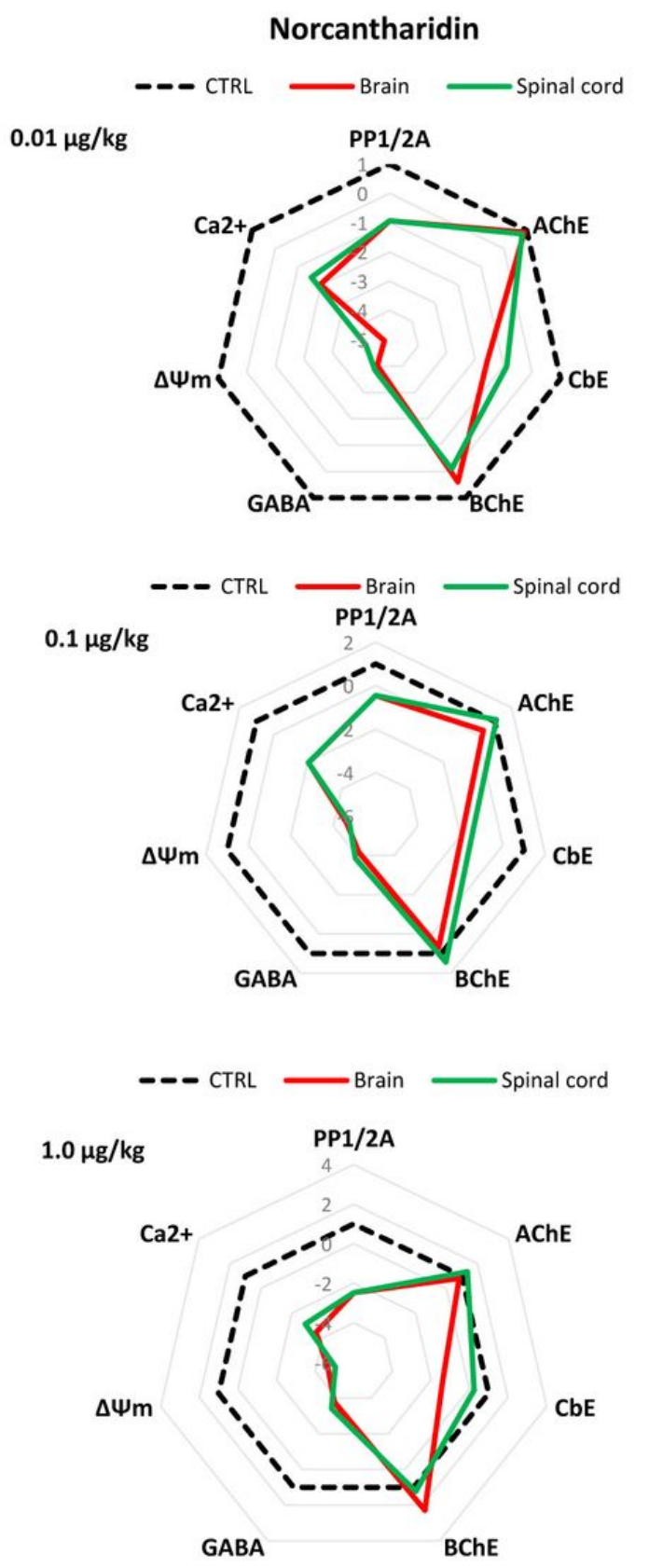

Figure 5

Star plot areas obtained from Integrated Biological Response version 2 in the brain and spinal cord of the Nile tilapia (Oreochromis niloticus) treated with different concentrations of Microcystis aeruginosa extract (left panels) and with different doses of norcantharidine (right panels). 